\title{
Physiological and Psychological Response Using a Buffer Space in Winter When Occupants Enter a Room from Outdoors
}

\author{
Aya Yokoe (OHORI) ${ }^{1)}$, Satoru $\mathrm{KunO}^{2)}$, Guohai $\mathrm{Xu}^{3)}$, \\ Teruyuki SAITO ${ }^{2)}$ and Masayuki HARADA ${ }^{2)}$ \\ 1) Chubu Electric Power Co. Inc., 20-1 Azakitasekiyama, Oodaka-cho, Midori-ku, \\ Nagoya 459-8522, Japan \\ E-mail: Yokoe.Aya@chuden.co.jp \\ ${ }^{2)}$ Graduate School of Environmental Studies, Nagoya University, \\ Furo-cho, Chikusa-ku, Nagoya 464-0814, Japan \\ 3) Yamatake Corporation, 4-28-1 Nishirokugou, Ota-ku, Tokyo 144-0056, Japan \\ (received on December 21, 2006, accepted on April 6, 2007)
}

\begin{abstract}
This paper reports the influence of passing through a buffer space on psychological and physiological responses of moving from outdoors to interior rooms. We conducted experiments with and without passage through the buffer space and compared the results. We controlled the indoor air temperature in experiments without the buffer space, and controlled both the atrium and indoor air temperature in experiments with the buffer space. Results show that without the buffer space, some subjects felt 'uncomfortable' immediately after entering the room when the outdoor temperature was moderate. Furthermore, after some time had passed, female subjects felt 'uncomfortable'. In contrast, with the buffer space, the intermediate temperature of the buffer space reduced the physiological load. Results show that when occupants enter a room from outdoors, passage through a buffer space mitigates heat shock.
\end{abstract}

Key words: thermal comfort, thermal sensation, skin temperature, buffer space, experiment using subjects

\section{Introduction}

Office workers have various working styles. Therefore, it is preferable to adjust the air-conditioning temperature settings to suit each worker; thereby everyone could feel thermal comfort. However, temperature control by individuals is virtually impossible in an office building with a central air-conditioning system. Workers who enter a room from outdoors or who return outdoors from the room might experience large temperature differences. Reducing the physiological load might be possible using an effective airconditioning method, or using a buffer space such as an atrium.

In general, an atrium incurs a large air-conditioning load because of its large space and amount of glass used. Atria are recognized as typical buffer spaces; various studies have specifically examined their use in physical environments and their ventilation efficiency.

Thermal environments of variously shaped atria in Japan have been investigated (Yoshino et al., 1996); other studies used CFD to elucidate characteristics of the indoor thermal environment of atria (Suwa et al., 1997; Hiramatsu et al., 1998). Another paper presented a simple atrium environment along with evaluation of the influence of radiant heat (Kohri et al., 2000). Studies have also examined preferable levels insolation of an atrium (Oyama et al., 1998), atrium design for natural ventilation (Holford et al., 2003), and ventilation and thermal environments in the atrium (Xu et al., 2004, 2005).

Nevertheless, few papers have discussed appropriate operation methods for air-conditioning according to occupants' physiological and psychological responses. Nakano et al. used laboratory experiments to examine buffer spaces' thermal effectiveness (Nakano et al., 2003). However, few studies are based on actual situations in which participants enter a room from outdoors or who return outdoors from the room.

Accordingly, the present study examined the effectiveness of a buffer space according to psychological and physiological responses of subjects who actually enter the room from outdoors after passing through 
the buffer space. That is, we elucidated the relative time necessary for physiological and psychological states to revert to a steady state after subjects enter a room from outdoors in conditions with and without passage through the buffer space.

\section{Research method}

\subsection{Experimental procedure}

Two types of experiment were conducted: a laboratory study in which participants entered the room directly from outdoors, and a field study in which participants entered the room from outdoors after passage through a buffer space. When not passing through the buffer space, the subjects entered the laboratory in Nagoya University after walking outdoors for $20 \mathrm{~min}$ at night. Then they stayed in the laboratory for $120 \mathrm{~min}$ during the winter of 2002-2003. For assessment of passage through the buffer space, Table 1 shows the field study experimental procedure. Subjects imitated (a) a morning commute, and (b) going out after lunch, etc. during the winter of 2004. The routes taken were: (a) (morning commute) station - train - station - outdoor - atrium - corridor workspace; and (b) (going out after lunch) workspace - corridor - atrium - outdoor - station - out door-atrium - corridor-workspace.

For comparison, data of psychological and physiological responses, such as skin temperature, without the buffer space were used.

\subsection{Experimental conditions}

For the experiment in which subjects did not pass through the buffer space, the laboratory temperature was set to $22^{\circ} \mathrm{C}$ and $25^{\circ} \mathrm{C}$, the latter being considered higher than usual.

For the field study passing through the buffer space, the atrium temperature was set to $17^{\circ} \mathrm{C}, 19^{\circ} \mathrm{C}$ or $21^{\circ} \mathrm{C}$; the workspace was $22^{\circ} \mathrm{C}$ or $24^{\circ} \mathrm{C}$.

Other items of humidity, wind speed, and insolation were not controlled.

\subsection{Items measured}

The following items were measured in both experiments. 1) Physiological responses, which were recorded at short intervals of $10 \mathrm{~s}-1 \mathrm{~min}$, were skin temperature (forehead, chest, forearm, thigh, and shin) (Logger Temperature 8, Probe LT-ST08-12; Gram Co.), and heart rate (Heart rate monitor FSseries, Polar Electro). 2) Psychological responses, which were recorded every 5-10 $\mathrm{min}$, were thermal sensation, thermal comfort (1, extremely uncomfortable; 2, uncomfortable; 3 , slightly uncomfortable; 4, neutral; 5 , slightly comfortable; 6 , comfortable; 7 , extremely comfortable), and the thermal sensation of each part of the body assessed using a questionnaire.
Table 1. Procedure of the experiment in the field study.

\begin{tabular}{|c|c|c|c|}
\hline $\begin{array}{c}\text { Shedule } \\
\text { time }\end{array}$ & & Experimental situation & State of sujects \\
\hline $7: 30$ & & \multicolumn{2}{|c|}{ gathering / receive the explanation of the experiment } \\
\hline $8: 20$ & & move to Rokugo Dote Station (walking outdoor) & wear a coat \\
\hline $8: 29$ & & move to Kachidoki station (by train) & \multirow[b]{2}{*}{$\begin{array}{l}\text { measurement start } \\
\text { /answer the }\end{array}$} \\
\hline $9: 10$ & & walk to Kachidoki Station to the atrium & \\
\hline $9: 27$ & (a) & Soon after entering the atrium & \multirow{3}{*}{ answer the questionnaire } \\
\hline $9: 29$ & & center of the atrium & \\
\hline $9: 31$ & & enter office tower Z & \\
\hline 9:35 & & entering the work space at 3 rd floor & $\begin{array}{l}\text { taking off a coat/ answer } \\
\text { the questionnaire }\end{array}$ \\
\hline $9: 40$ & & \multirow[b]{2}{*}{ answer the questionnaire every $5 \mathrm{~min}$. } & \multirow{4}{*}{ answer the questionnaire } \\
\hline$\frac{\downarrow}{10: 05}$ & & & \\
\hline & & & \\
\hline $10: 35$ & & answer the questionnaire every $10 \mathrm{~min}$. & \\
\hline & & rest of $10 \mathrm{~min} . /$ drink & rest \\
\hline $10: 45$ & & \multirow[b]{2}{*}{ answer the questionnaire every $10 \mathrm{~min}$. } & \multirow{10}{*}{ answer the questionnaire } \\
\hline 11.15 & & & \\
\hline$\frac{11: 15}{11: 18}$ & & enter office tower Z & \\
\hline $11: 20$ & & soon after entering the atrium & \\
\hline $11: 22$ & & center of the atrium & \\
\hline $11: 24$ & & enter office tower Z & \\
\hline $11: 27$ & & enter the work space at 3rd floor & \\
\hline $11: 32$ & & \multirow{3}{*}{ answer the questionnaire every $5 \mathrm{~min}$. } & \\
\hline & & & \\
\hline 11:57 & & & \\
\hline & & lunch time & lunch \\
\hline $12: 30$ & & enter office tower $Z$ & \multirow{18}{*}{ answer the questionnaire } \\
\hline $12: 32$ & & soon after entering the atrium & \\
\hline$\frac{1.32}{12: 34}$ & & center of the atrium & \\
\hline $12: 36$ & (b) & soon after going outdoors & \\
\hline $12: 50$ & & walking outdoors & \\
\hline $13: 06$ & & soon after entering the atrium & \\
\hline $13: 08$ & & center of the atrium & \\
\hline $13: 10$ & & enter office tower Z & \\
\hline $13: 15$ & & enter the work space at 3rd floor & \\
\hline $13: 20$ & & \multirow{3}{*}{ answer the questionnaire every $5 \mathrm{~min}$. } & \\
\hline & & & \\
\hline $13: 45$ & & & \\
\hline$\frac{\downarrow}{14.15}$ & & answer the questionnaire every $10 \mathrm{~min}$. & \\
\hline$\frac{14: 13}{14: 18}$ & & enter office tower $Z$ & \\
\hline $14: 20$ & & soon after entering the atrium & \\
\hline$\frac{14.20}{14: 22}$ & & center of the atrium & \\
\hline $14: 24$ & & soon after going outdoors & \\
\hline $14: 30$ & & stay outdoors & \\
\hline
\end{tabular}

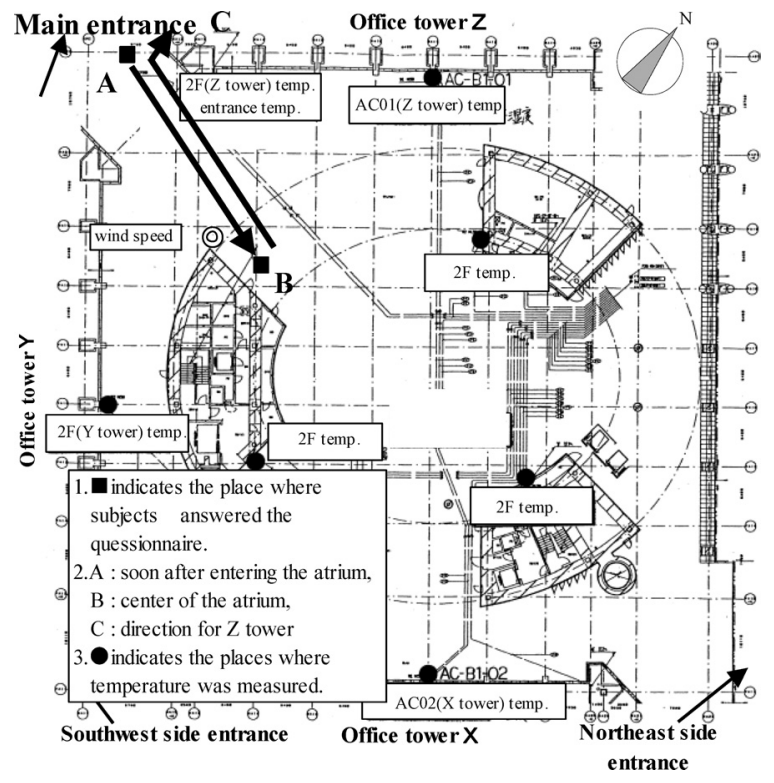

Fig. 1. Measurement points in the atrium.

3) Environmental factors, which were measured every minute, were air temperature, humidity, wind speed, and insolation.

Figure 1 shows each measurement point in the atrium as a buffer space. In the figure, solid circles denote temperature and humidity measurement places and solid squares denote places where subjects answered the questionnaire. Wind speed was meas- 
Table 2. Average outdoor temperature, wind speed and laboratory temperature in the laboratory study.

\begin{tabular}{|c|c|c|c|c|c|c|c|c|c|c|c|c|c|}
\hline \multirow[b]{2}{*}{ Sub. } & \multirow[b]{2}{*}{ Gender } & \multicolumn{6}{|c|}{ Condition 22} & \multicolumn{6}{|c|}{ Condition 25} \\
\hline & & $\begin{array}{l}\text { Outdoor } \\
\text { temp. }\left({ }^{\circ} \mathrm{C}\right)\end{array}$ & S.D. & $\begin{array}{c}\text { Wind } \\
\operatorname{speed}(\mathrm{m} / \mathrm{s})\end{array}$ & S.D. & $\begin{array}{l}\text { Lab. temp. } \\
\left.\text { ( }{ }^{\circ} \mathrm{C}\right)\end{array}$ & S.D. & $\begin{array}{l}\text { Outdoor } \\
\text { temp. }\left({ }^{\circ} \mathrm{C}\right)\end{array}$ & S.D. & $\begin{array}{c}\text { Wind } \\
\operatorname{speed}(\mathrm{m} / \mathrm{s})\end{array}$ & S.D. & $\begin{array}{l}\text { Lab. temp. } \\
\text { ( } \mathrm{C})\end{array}$ & S.D. \\
\hline $\mathrm{A}$ & $\mathrm{M}$ & 5.83 & 0.06 & - & - & 22.0 & 0.5 & 9.61 & 0.07 & - & - & 25.7 & 0.7 \\
\hline $\mathrm{C}$ & $\mathrm{M}$ & 6.91 & 0.08 & - & - & 21.3 & 1.3 & 8.42 & 0.13 & - & - & - & - \\
\hline $\mathrm{D}$ & $\mathrm{M}$ & 8.46 & 0.10 & - & - & 21.7 & 0.4 & 10.47 & 0.05 & - & - & 24.1 & 0.2 \\
\hline $\mathrm{G}$ & $\mathrm{M}$ & 4.95 & 0.08 & - & - & 21.8 & 0.6 & 3.03 & 0.08 & - & - & 23.6 & 0.2 \\
\hline $\mathrm{S}$ & $\mathrm{F}$ & 5.95 & 0.12 & - & - & 23.0 & 2.2 & 7.27 & 0.07 & 0.60 & 0.37 & 25.9 & 1.8 \\
\hline $\mathrm{T}$ & $\mathrm{F}$ & 8.08 & 0.10 & 1.00 & 0.75 & 23.3 & 2.2 & 4.40 & 0.06 & 0.79 & 0.62 & 25.4 & 1.6 \\
\hline $\bar{U}$ & $\mathrm{~F}$ & 8.23 & 0.10 & 1.25 & 0.55 & 22.5 & 0.8 & 8.27 & 0.07 & 0.75 & 0.63 & 25.6 & 1.6 \\
\hline $\mathrm{V}$ & $\mathrm{F}$ & 6.51 & 0.05 & 0.75 & 0.56 & 23.4 & 2.0 & 6.28 & 0.06 & 1.05 & 0.81 & 25.9 & 1.7 \\
\hline $\mathrm{W}$ & $\mathrm{F}$ & 5.95 & 0.12 & - & - & 23.0 & 2.2 & 5.91 & 0.09 & 0.90 & 0.70 & 25.9 & 2.2 \\
\hline
\end{tabular}

ured at the top of the atrium, and insolation was measured walking next to subjects.

\subsection{Subjects}

The laboratory experiment included seven male (sub. A, B, C, D, E, F, and G) and eight female (sub. S, T, U, V, W, X, Y, and Z) participants. Each subject was tested at both $22^{\circ} \mathrm{C}$ and $25^{\circ} \mathrm{C}$ laboratory temperatures. One subject was tested individually on a given day. Therefore, the results were analyzed from individual data. In the field study, four males and four females were tested on the same experimental day. Subjects were not always the same between experimental days. Therefore, results were analyzed from these four subjects' averaged data.

Thermal insulation of clothing was estimated in both experiments as about 1.0 clo in the room and 1.6-1.7 clo outdoors.

\section{Results and Discussion}

\subsection{Achieved thermal environment}

Table 2 shows the average temperature and wind speed outdoors and laboratory air temperatures in the laboratory study. Figure 2 shows changes in air temperatures, wind speed and insolation outdoors in the field study. Figure 3 shows air temperature changes in the atrium and workspace in the field study. In these figures, abbreviated forms of explanatory notes are described according to this example: the atrium temperature setting is $18^{\circ} \mathrm{C}$ and the workspace setting is $24^{\circ} \mathrm{C}$ in $\mathrm{A} 18 \mathrm{~W} 24$, whereas the notation inside parentheses is an actual measured value of the temperature that was averaged by the time that subjects stayed in each place.

Table 2, Fig. 2, and Fig. 3 show that physical changes aside from temperature exhibited almost no differences between the experimental days. Some studies have shown that air temperature is the most influential factor outdoors (Ishii et al., 1989). Therefore, we examine the temperature difference in this paper. The temperature change during $20 \mathrm{~min}$ of outdoor exposure was small, within $\pm 0.2^{\circ} \mathrm{C}$, but the temperature difference with the experimental day was large: $3-14^{\circ} \mathrm{C}$. The average air temperature in the laboratory therefore fluctuated within $\pm 1.0^{\circ} \mathrm{C}$ of the set temperature. The actual temperature adequately achieved the preset temperature. In the field study, changes in the outdoor air temperature, the atrium, and workspace over time are as shown in Fig. 2. The change in outdoor temperatures was $3-11^{\circ} \mathrm{C}$, which was almost equal to that of the laboratory study. The air temperature around the atrium entrance was about $2^{\circ} \mathrm{C}$ lower than the atrium's set temperature, but the average temperature (average of measurements at three points in the atrium) almost achieved the set temperature. The air coming in through the entrance might have reduced the temperature near the entrance. Regarding the workspace, when the temperature was set at $22^{\circ} \mathrm{C}$, the actual temperature was about $0.5-3^{\circ} \mathrm{C}$ higher; it was about $0.5-2^{\circ} \mathrm{C}$ higher when the temperature was set at $24^{\circ} \mathrm{C}$. Therefore, we used a measured temperature of each space.

\subsection{Psychological response by passage through the buffer space}

Figure 4 shows the relationships among the outdoor temperature, the atrium temperature, and the thermal comfort level soon after entering the atrium in the laboratory study. The figure shows the averaged values of thermal comfort soon after entering the atrium. More subjects felt 'comfortable' immediately after entering the atrium when the outdoors and atrium were moderate. Moreover, for equivalent outdoor temperatures, subjects felt more 'comfortable' in the experimental day with higher atrium temperature than with the lower atrium temperature. There- 


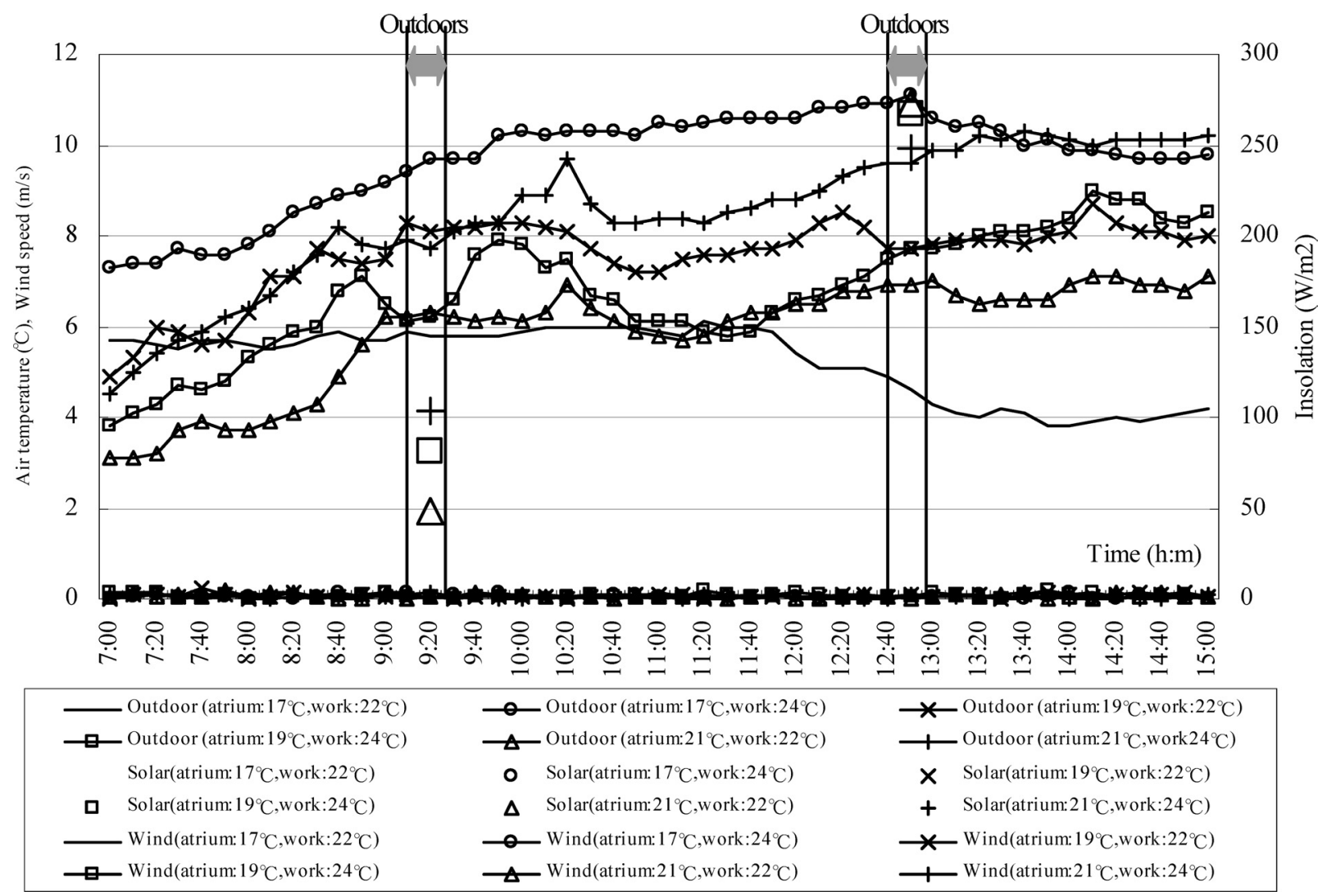

Fig. 2. Changes in air temperatures, wind speed and insolation outdoors (field study).

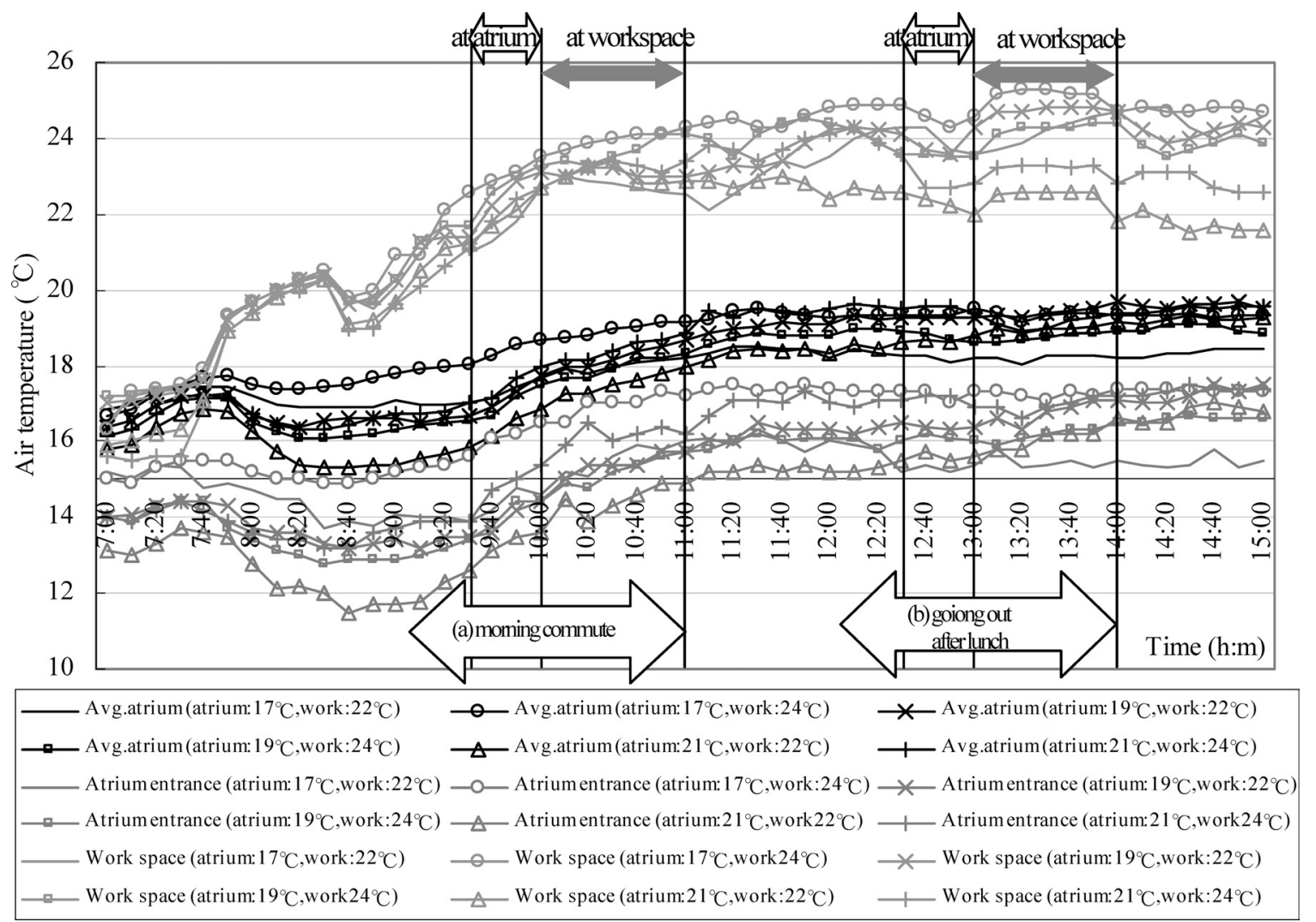

Fig. 3. Air temperature changes in the atrium and workspace (field study). 
fore, the atrium temperature influenced thermal comfort more strongly than the outdoor temperature did. Participants felt 'comfortable' immediately after entering the atrium if the atrium temperature was higher than $15^{\circ} \mathrm{C}$, even though the outdoor temperature was $4^{\circ} \mathrm{C}$. Consequently, the higher the atrium temperature, the more 'comfortable' subjects felt immediately after entering the atrium. For that effect, a tem-

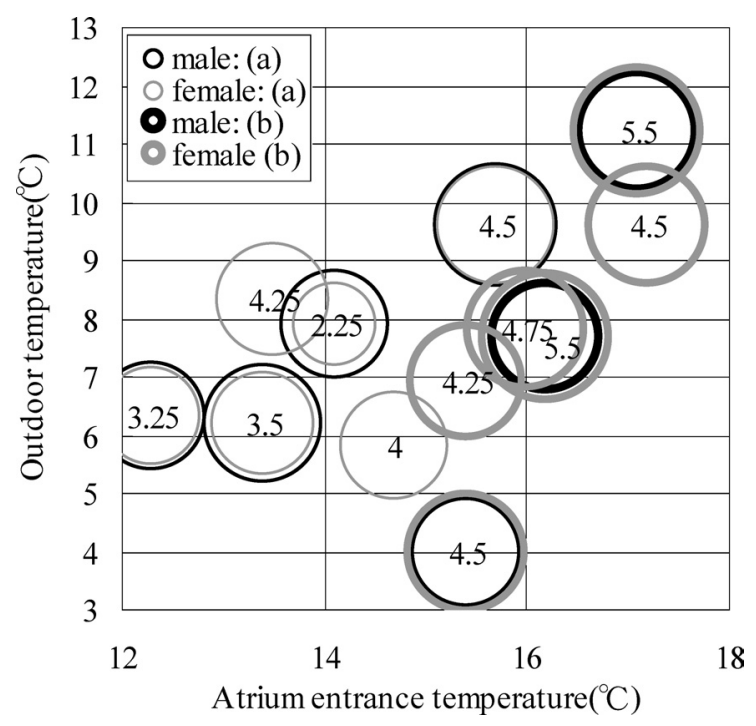

Fig. 4. Relationships among the outdoor temperature, the atrium temperature and thermal comfort in the field study. perature higher than $15^{\circ} \mathrm{C}$ is sufficient for the atrium. This result shows that occupants are satisfied with the atrium's thermal environment if its temperature is above $15^{\circ} \mathrm{C}$ when the outdoor temperature is $3-11^{\circ} \mathrm{C}$. These results agree with those of a previous study (Otsuka et al., 1989), which revealed that a lower temperature setting is the best way to achieve occupants' satisfaction when they enter a room from outdoors.

Figure 5 shows the change in thermal comfort after entering the workspace in the field study. Some male subjects felt 'uncomfortable' in the $17^{\circ} \mathrm{C}$ condition at the atrium and $24^{\circ} \mathrm{C}$ at the workspace. The outdoor temperature of this condition was higher than $9^{\circ} \mathrm{C}$; the workspace was warmer than $25^{\circ} \mathrm{C}$ (Fig. 2).

These results resembled those of the laboratory study. Some subjects felt 'uncomfortable' immediately after entering the room. Others felt 'uncomfortable' after some time had elapsed.

Table 3 shows the change in thermal comfort level after entering the room in the laboratory study. Regarding details of 'uncomfortable' immediately after entering the laboratory, Fig. 6 depicts the relationship between the outdoor temperature and thermal comfort level soon after entering the laboratory. This figure shows that whenever the outdoor temperature became higher than $9.0^{\circ} \mathrm{C}$, both male and female sub-

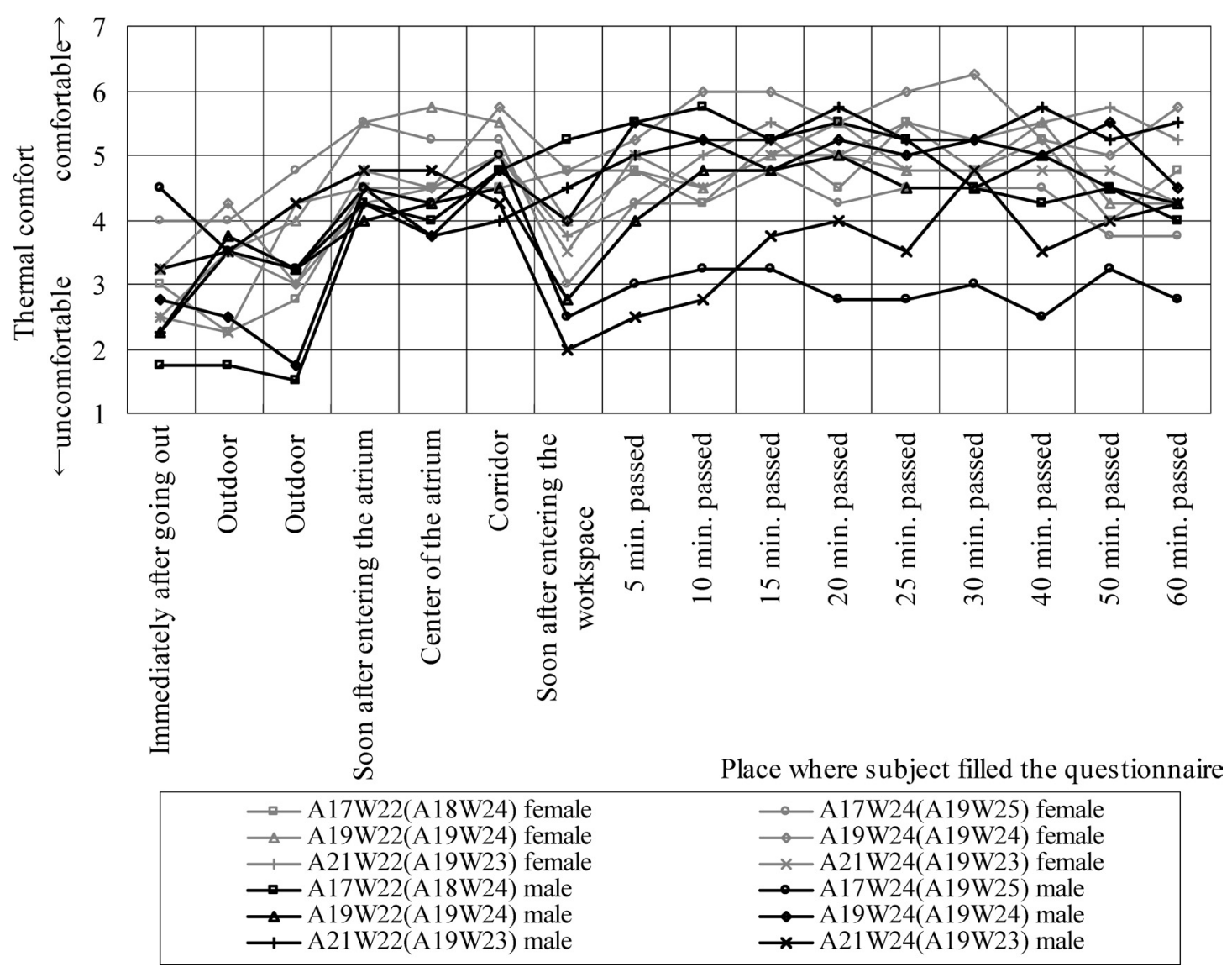

Fig. 5. Changes in thermal comfort level from the state of (b): going out after lunch to the state of staying the workspace. 
Table 3. Changes in the thermal comfort level in the laboratory study.

(A) Condition 22
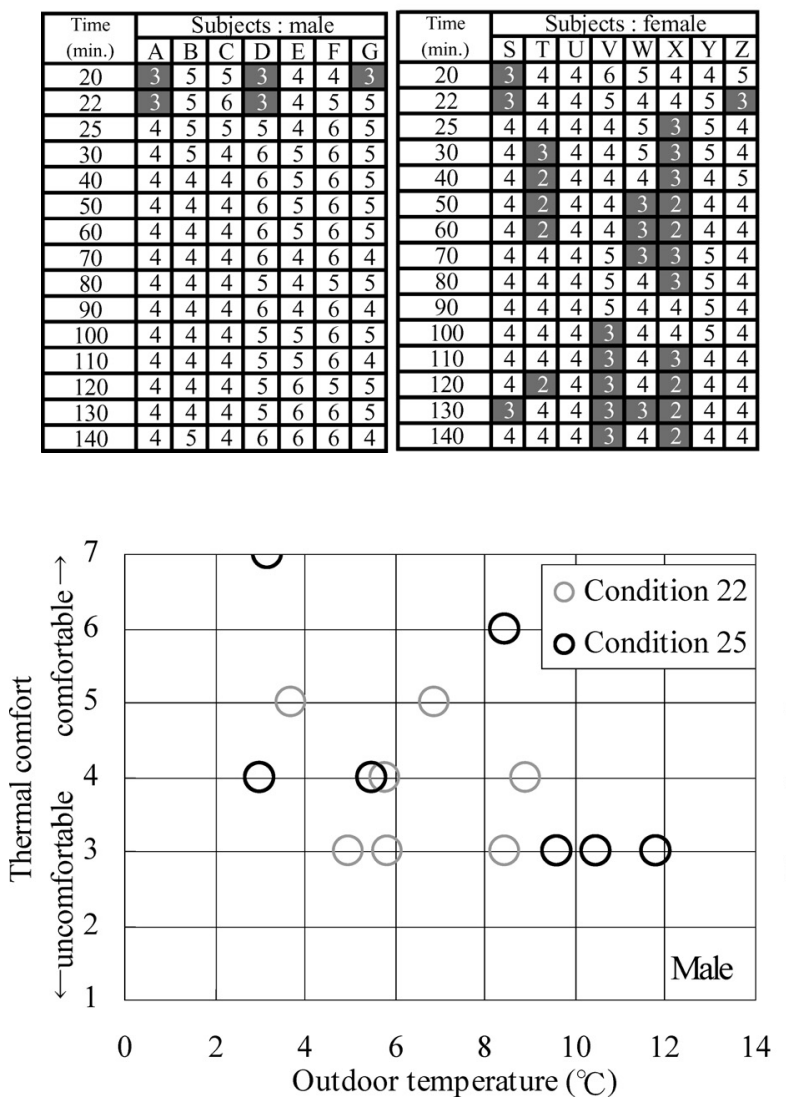

(B) Condition 25
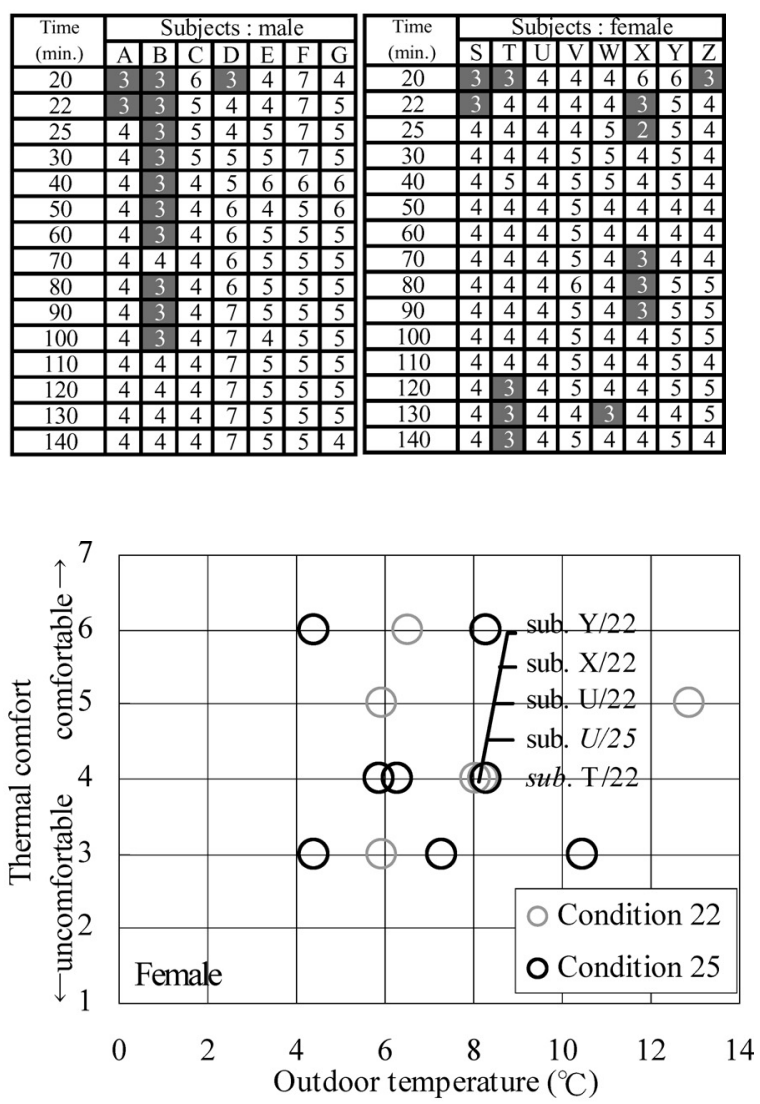

Fig. 6. Relationship between outdoor temperature and thermal comfort level soon after enter the laboratory.

jects felt 'uncomfortable' at the setting of $25^{\circ} \mathrm{C}$ in the laboratory. Therefore, a temperature setting of $25^{\circ} \mathrm{C}$ is apparently too warm when the outdoor temperature is higher than $9.0^{\circ} \mathrm{C}$.

Thermal comfort of male subjects after entering the room tended to be similar to that in the case without the buffer space, although female subjects did not feel 'uncomfortable' with the buffer space if outdoor and indoor thermal conditions were equivalent. Therefore, a difference was apparent in the psychological influence imparted between genders by passing through the buffer space. The results suggest that almost no psychological influence was felt by males when passing through the buffer space, but some psychological effects might be imparted on females.

\subsection{Physiological response to passing through the buffer space}

Figure 7 shows changes in skin temperature after entering the laboratory in the laboratory study. Skin temperatures change from the start of the experiment: they increase about $3^{\circ} \mathrm{C}$ during the first $4-5 \mathrm{~min}$ after subjects enter the room from outdoors.

Figure 8 shows the skin temperature elevation in the field study. This figure shows the temperature

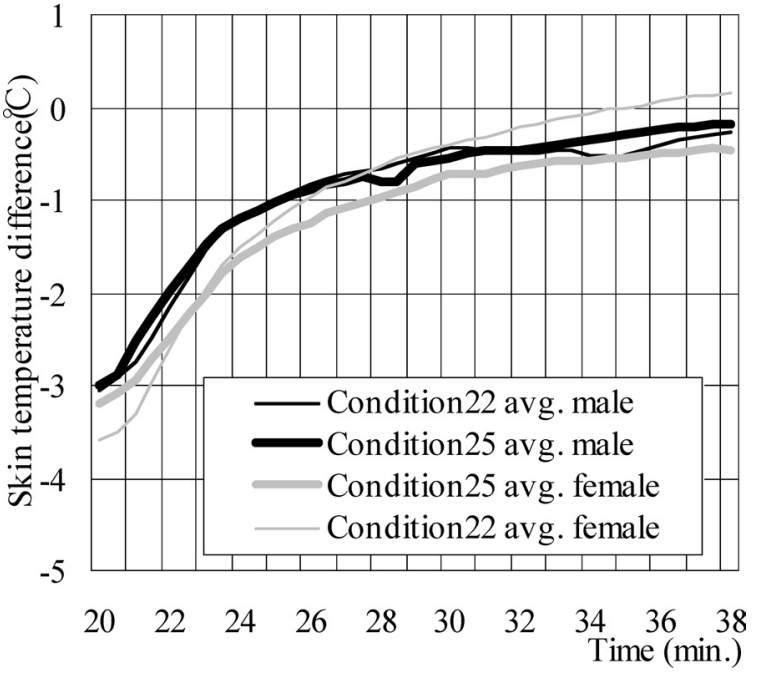

Fig. 7. Change in mean skin temperature elevation after entering the laboratory in the laboratory study.

changes similarly to those in Fig. 7: skin temperatures change from the start of the experiment. The figure clarifies that skin temperature rises less than $2{ }^{\circ} \mathrm{C}$; the temperature elevation is more gradual than that of the laboratory study. A previous study (Gagge et al., 1967) showed that within $31.5-35.5^{\circ} \mathrm{C}$ the av- 
erage skin temperature steady state is about $33.2^{\circ} \mathrm{C}$; no reports of discomfort were given.

A more detailed presentation is the relationship between the difference in air temperature and the mean skin temperature elevation at each stage, as shown in

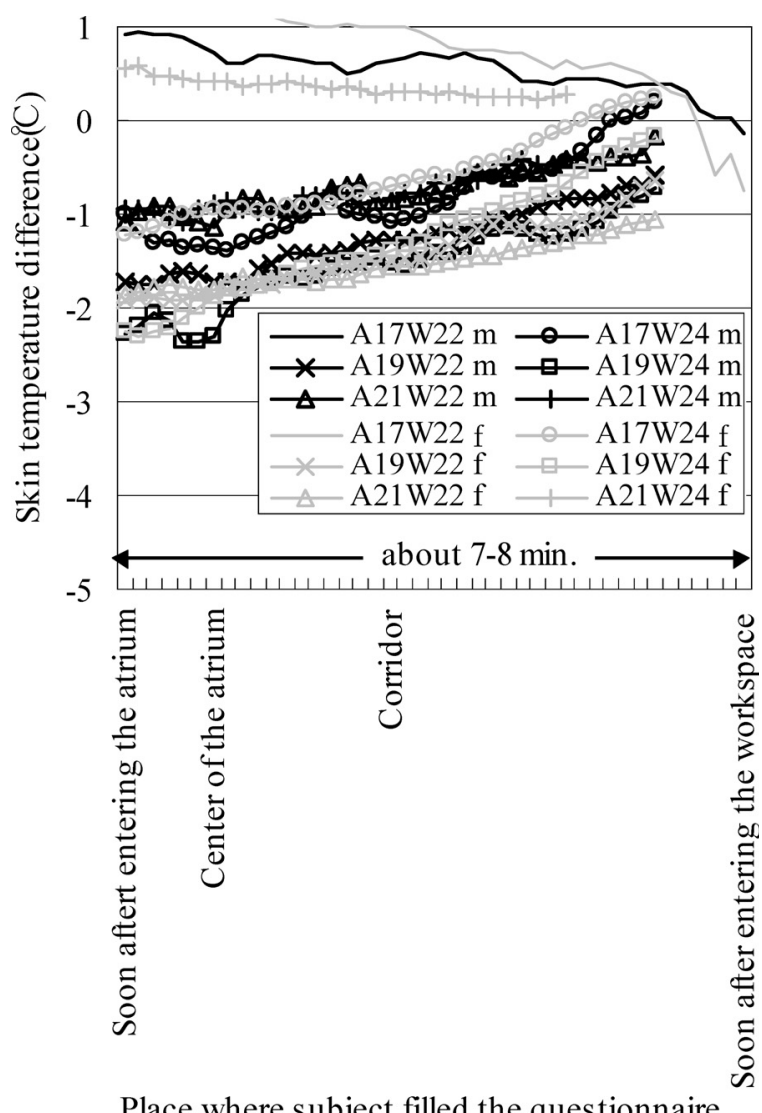

Place where subject filled the questionnaire

Fig. 8. Change in mean skin temperature elevation after entering the workspace through the atrium in the field study.
Fig. 9. The figure shows that skin temperatures change until moving to the next space. The mean increase in skin temperature when subjects entered the atrium from outdoors was less than $0.7^{\circ} \mathrm{C}$, but the air temperature difference was greater than $9^{\circ} \mathrm{C}$. In contrast, the mean increase in skin temperature when subjects entered the workspace from the corridor was greater than $1.5^{\circ} \mathrm{C}$ on some days, but the air temperature difference was about $7^{\circ} \mathrm{C}$. This result reflects the fact that it took time to enter the workspace from outdoors through the atrium. Consequently, the change in mean skin temperature followed accordingly, even though a great difference existed in air temperature when the subjects entered the atrium from outdoors. Skin temperature rose gradually as subjects passed through the atrium and corridor.

Furthermore, Fig. 10 shows the heart rate change of one male subject from the start of the experiment in the laboratory study; Fig. 10 shows field study data. Fig. 10 clarifies that the heart rate reverts to the steady state in $10 \mathrm{~min}$ after entering the room from outdoors. In contrast, Fig. 11 shows the result of field study: it took about $5 \mathrm{~min}$ to revert to the steady state after entering the workspace from outdoors. The intermediate buffer space temperature decreased the physiological load.

\section{Conclusions}

Individuals' desired thermal environments would be provided and dissatisfied occupants would be decreased if personal air-conditioning systems were used, but such systems are prohibitively expensive. Passage through a buffer space is a practical alternative.

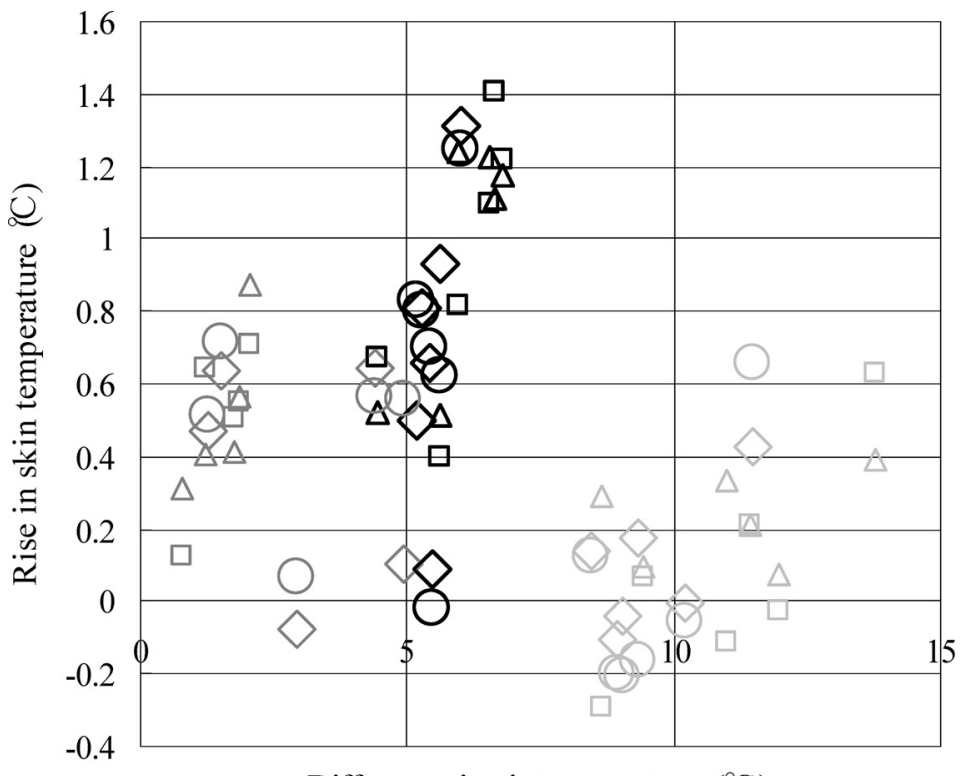

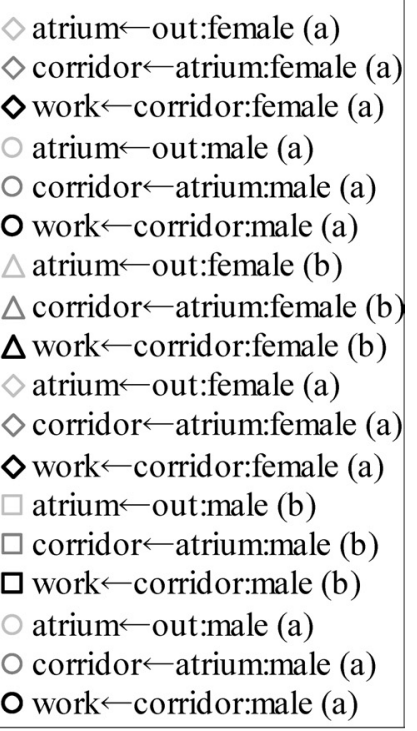

$\checkmark$ atrium $\leftarrow$ out:female (a)

$\checkmark$ corridor $\leftarrow$ atrium:female (a)

work $\leftarrow$ corridor:female (a)

out:male (a)

$\triangle$ atrium $\leftarrow$ out:female

$\triangle$ corridor $\leftarrow$ atrium:female $(b)$

$\Delta$ work $\leftarrow$ corridor:female (b)

atrium $\leftarrow$ out:female (a)

corridor $\longleftarrow$ atrium:female (a)

$\diamond$ work $\leftarrow$ corridor:female (a)

$\square$ atrium $\leftarrow$ out:male (b)

corridor $\longleftarrow$ atrium:male (b)

dor:male (b)

O corridor $\longleftarrow$ atrium:male (a)

O work $\leftarrow$ corridor:male (a)

Difference in air temperature $\left({ }^{\circ} \mathrm{C}\right)$

Fig. 9. Relationship between air temperature difference and skin temperature rising in the field study. 


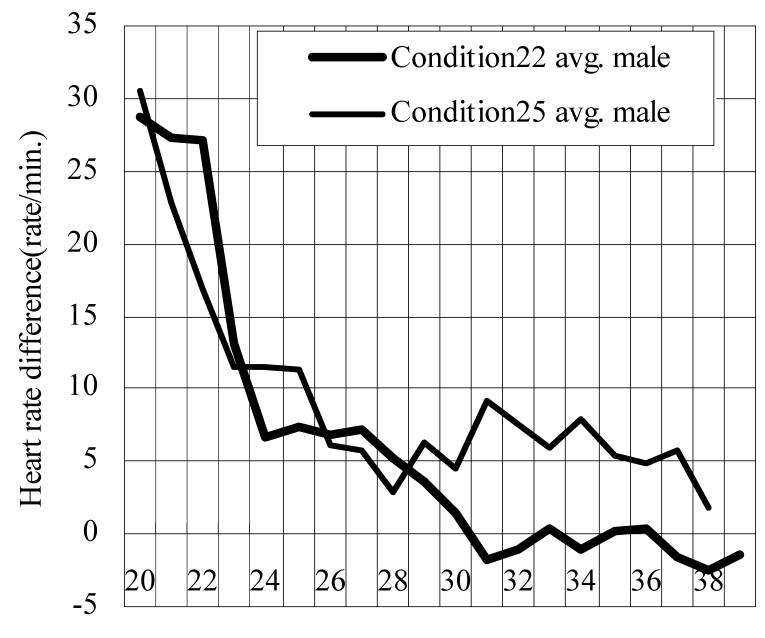

Time(min.)

Fig. 10. Change in heart rate after entering the laboratory in the laboratory study.

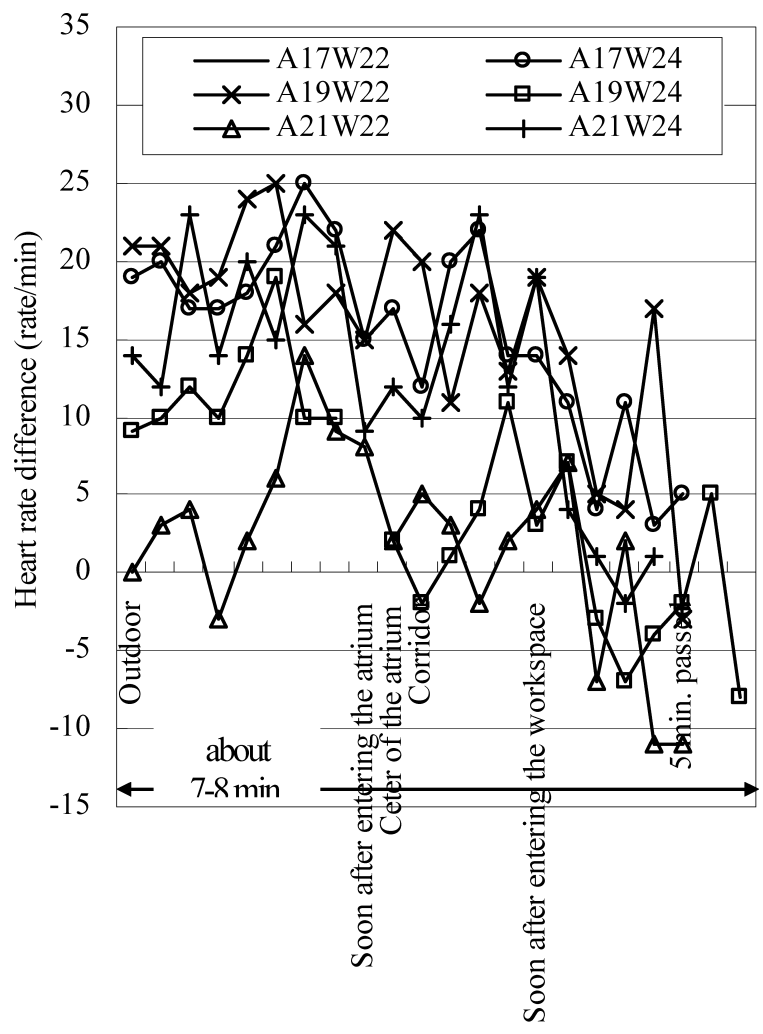

Place where subject filled the questionnaire

Fig. 11. Change in heart rate after entering the workspace through the atrium in the field study.

We sought to assess differences of psychological and physiological responses using a laboratory study without a buffer space and the field study with a buffer space.

Regarding psychological results, subjects felt 'uncomfortable' at laboratory temperatures of $25^{\circ} \mathrm{C}$ when outdoors temperatures were greater than $9^{\circ} \mathrm{C}$ in the laboratory study without the buffer space. In the field study with the buffer space, some male subjects also felt 'hot' and 'uncomfortable' at room temperatures higher than $25^{\circ} \mathrm{C}$. Therefore, almost no influence is exerted on psychological response by passing through the buffer space. Subjects felt 'comfortable' immediately after entering the atrium as a buffer space if the atrium temperature was greater than $15^{\circ} \mathrm{C}$. A temperature greater than $15^{\circ} \mathrm{C}$ is sufficient for psychological satisfaction immediately after coming indoors.

Regarding physiological results, skin temperatures rose gradually by passage through the buffer space. Furthermore, the heart rate steadied immediately after entering the workspace after passage through the buffer space. These results show that the physiological load might be reduced by passage through a buffer space.

This study assessed physiological effects using the atrium as a buffer space: the psychological effect was negligible. In winter, the intermediate temperature of the buffer space reduced the physiological load imparted by the sudden change in temperature.

\section{Acknowledgments}

This research was supported in part by a Grant-inAid for Scientific Research from the Ministry of Education, Culture, Sports, Science and Technology (to Satoru Kuno). Yamatake Corp., Nikken Sekkei Ltd., and Harumi Corp. Inc. also sponsored this study. The authors thank all participants in experiments.

\section{References}

Gagge, A. P., Stolwik, J. A. J., Hardy, J. D. (1967) Comfort and thermal sensations and associated physiological responses at various ambient temperatures. Environmental Research 1: 1-20.

Hiramatsu, T., Harada, T., Kato, S., Murakami, S., Yoshino, H. (1998) Analysis of indoor thermal environment with cooling condition and natural ventilation. J. Archit. Plan. Environ. Eng., AIJ 513: 23-30 (in Japanese).

Holford, J. M., Hunt, G. R. (2003) Fundamental atrium design for natural ventilation. Building and Environment 38: 409-426.

Ishii, A., Katayama, T., Shioduki, Y., Yoshinaga, Y., Abe, Y. (1989) A study on the thermal sensation in outdoor environment: J. Archit. Plan. Environ. Eng., AIJ 386: 28-36 (in Japanese).

Kohri, K., Ishino, H., Furukawa, T. (2000) A study on evaluation of radiant effect from each surface in atria through field measurement. J. Archit. Plan. Environ. Eng. AIJ 535: 9-14 (in Japanese).

Nakano, J., Tanabe, S. (2003) Transient thermal comfort succeeding a short walk from indoor to outdoor. Journal of Environmental Engineering, Transactions of AIJ 565: $33-40$.

Otsuka, S., Ito, N., Ishino, H., Hanada, K., Sasaki, M. (1989) A study on the optimum space temperature in 
case of entering a room from outdoors in winter. Collection of synopses, AIJ 883-884 (in Japanese).

Oyama, Y., Nishimura, M., Inui, M. (1998) A study of daylight with sunbeam in atria. J. Archit. Plan. Environ. Eng., AIJ 503: 69-76 (in Japanese).

Suwa, Y., Fujii, S., Yuasa, K., Sato, Y. (1997) Studies on characteristics of indoor thermal environment and airconditioning load in atriums with openings. J. Archit. Plan. Environ. Eng., AIJ 491: 41-48 (in Japanese).

Xu, G., Okagaki, A., Sekine, T., Yamanaka, Y. (2004) A field study on the optimum air-conditioning operating method for a large-scale grand lobby: Proc. of the 7th International Symposium on Building and Urban Environmental Engineering, 147-154.

Xu, G., Kuno, S., Ohori, A., Saito, T. (2005) The Optimum Air-conditioning Operating Method for a Large-scale Grand Lobby. Proceedings of Indoor Air 2005: 776-781.

Yoshino, H., Ito, K., Aozasa, K. (1996) Trends in thermal environment design of atrium building in Japan. J. Archit. Plan. Environ. Eng., AIJ 483: 63-72 (in Japanese). 